\title{
The construction of a territorial organization of primary care stakeholders facing the covid-19 epidemic: contributions of a case study at the canton level
}

Cécile Fournier and Pascal Clerc

\section{CpenEdition}

\section{Journals}

Electronic version

URL: http://journals.openedition.org/rfst/874

DOI: $10.4000 /$ rfst. 874

ISSN: 2492-3672

Publisher

Espaces et SOciétés (UMR 6590)

Electronic reference

Cécile Fournier and Pascal Clerc, "The construction of a territorial organization of primary care stakeholders facing the covid-19 epidemic: contributions of a case study at the canton level", Revue francophone sur la santé et les territoires [Online], Pandemic, crises and perspectives: territorial readings of Covid-19, Online since 11 March 2021, connection on 06 April 2021. URL: http:// journals.openedition.org/rfst/874 ; DOI: https://doi.org/10.4000/rfst.874

This text was automatically generated on 6 April 2021.

\section{(i) (2) (2)}

La Revue francophone sur la santé et les territoires est mise à disposition selon les termes de la Licence Creative Commons Attribution - Pas d'Utilisation Commerciale - Partage dans les Mêmes Conditions 4.0 International. 


\title{
The construction of a territorial organization of primary care stakeholders facing the covid-19 epidemic: contributions of a case study at the canton level
}

\author{
Cécile Fournier and Pascal Clerc
}

1 At the beginning of the Covid-19 epidemic in France, the mobilization of primary care professionals was not driven by the government, which focused its attention on hospitals. As a result of ministerial orders to delay medical consultations as much as possible and to close most of the paramedical practices, one might have expected that primary care activity would be strongly reduced and uncoordinated. However, in some territories, primary care actors consulter each other, adopting a systemic and population-based approach to the situation, which led them to propose a new organization on a scale that made sense to them. In a context of weak regulation of primary care, how does a territorial organization mobilizing private healthcare professionals build itself in times of epidemic? And to what extent does this construction rely on a pre-existing territorial action system, itself under construction?

2 We are exploring this issue at the cantonal level in a territory where the organization of primary care to deal with the epidemic has been particularly fluid. The case study conducted between March and September 2020 is based on a participatory observation approach by a physician-researcher and on interviews conducted by a sociologist with 21 local professionals: private healthcare professionals (general practitioners, paramedics, pharmacists, a biologist, coordinators and a secretary), hospital professionals and a member of the municipal team.

3 We studied a canton centered in a socio-economically disadvantaged urban metropolis, with a low provision of healthcare services. A territory where links between primary care actors have gradually been built up, following two main movements: an old 
medical and medico-social movement, which started in the commune of Meulan-enYvelines, and a more recent multi-professional and intersectoral movement, which began to develop in the commune of Les Mureaux, around a Multi-Professional Healthcare Home and a Local Health Contract involving the municipality. These two movements are now converging into a Professional Territorial Healthcare Community (PTHC) of ambulatory healthcare professionals from the canton and a few cities around. Its main objectives are better access to care, better care pathways, development of health promotion and professionals training.

4 Figure 1 shows private and public healthcare structures on the PTHC' territory, which are all included in the territory of the same Territorial Hospital Group.

5 The PTHC' members developed a systemic view on health issues related to the epidemic across the territory. They built an organization around two axes: on the one hand, for patients affected by the virus, outpatient care based on a Covid centre to ensure an upstream triage from the hospital, outpatient care and monitoring in pre- or posthospitalization. On the other hand, for patients not affected by the virus, an organization which performs two types of functions. The first is to facilitate the continuity of outpatient care by publicizing the initiatives of organizations in professional groups and by creating links between private professionals in the territory. The second is to foster the articulation between outpatient professionals and institutions contributing to primary care: organizing patients' pathways with hospital actors, and implementing screenings in immigrant workers' homes, with hospital actors and the municipal team.

6 This structuration was built on pre-existing relationships and organizations within the territory. During the epidemic, partnership dynamics developed by relying on the members of the THC and new actors joined the movement. Shared difficulties became more visible and previous intersectoral projects were unblocked. A new professional culture also emerged, with more participatory project management and decisionmaking, and changes in the way roles and occupations are viewed. It raised hopes that these collaborations will continue and strengthen.

7 Among our main findings, the role of the territory - through its actors, their interactions and their histories - appears central in the structuration of a primary care organization in times of epidemic, here through a PTHC. This experience provided a "full-scale test" of the ability of the PTHC actors to exercise a public health mandate. This was an opportunity for learning and cultural change, both for private professionals discovering collective action and population-based approaches within a "territorial health care team", and for the institutions that allowed this organization to be built and supported. The effects on reducing emergency room visits and improving patient pathways are still effective facing the second epidemic wave. This new way of building organizations, based on mutual trust between regulatory institutions and professionals acting together at a territorial scale that makes sense to them, raises several issues. Indeed, this experience questions the ability of this type of territorial action systems in primary care to build an organization adapted both to the needs of local actors and to the issues raised by political and regulatory institutions that intervene on a larger scale, in a system where professional, managerial and political logics can come into tension. It also questions the ability of PTHCs to develop a health promotion approach and to reduce social health inequalities. 
Figure 1: Administrative territories and territories of healthcare and medico-social groups of actors contributing to the Professional Territorial Healthcare Community (PTHC) Val-de-Seine

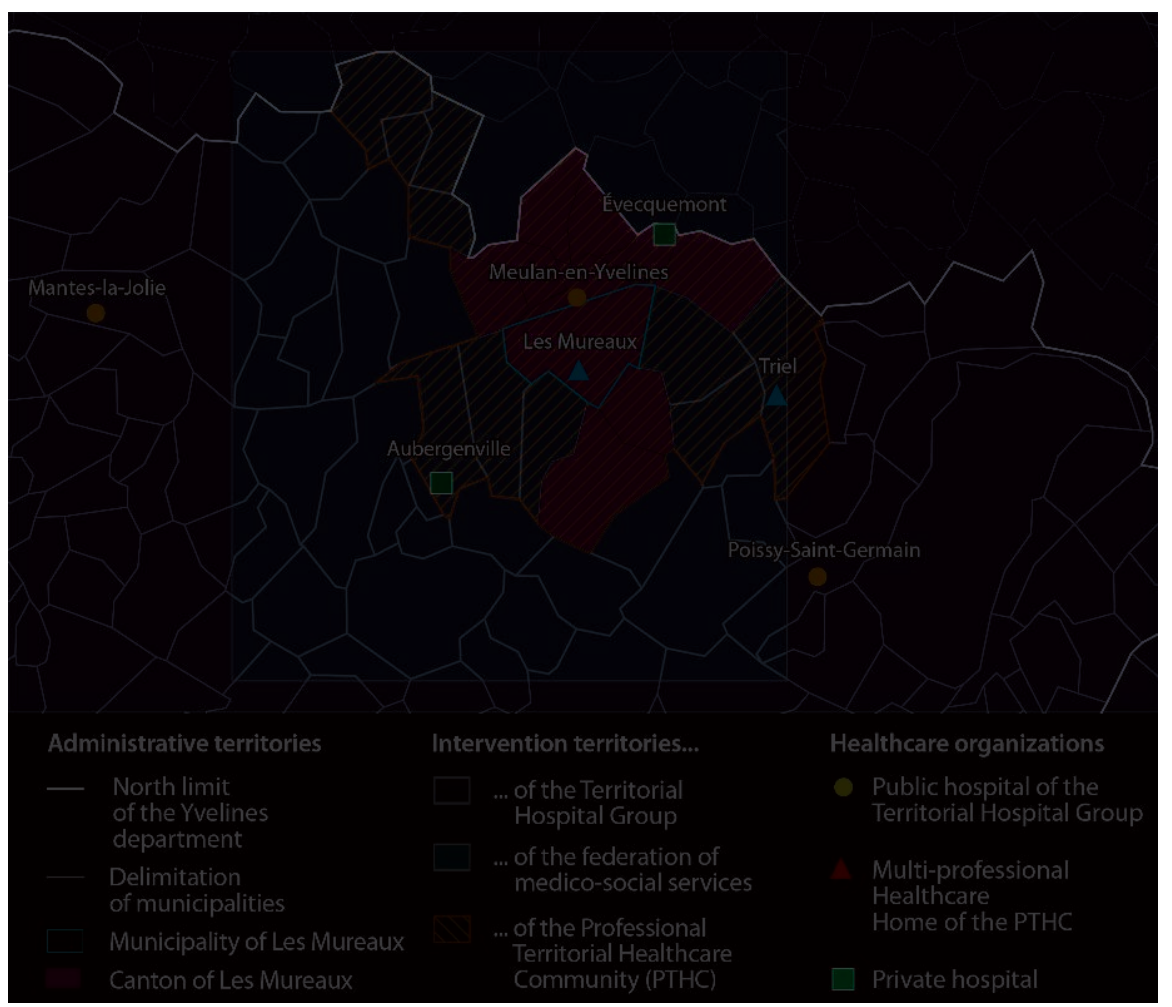

\section{AUTHORS}

\section{CÉCILE FOURNIER}

Maître de recherche, IRDES, 117 bis rue Manin 75019 Paris, France, Chercheure associée au LEPS EA 3412

\section{PASCAL CLERC}

Chercheur associé, Université Paris-Est-Créteil, INSERM, IMRB (CEpiA Team), F-94010 Créteil, France. Professeur associé, Université de Versailles-St Quentin en Yvelines, Département de médecine générale. Membre titulaire de la Société Française de Médecine Générale 